\title{
生物の生息地としての里山
}

\section{Satoyama as Reservoir of Fauna and Flora}

守山 弘*

Hiroshi MORIYAMA

\section{雑木林のスプリング・エフェメラル}

里山の中心である雑木林は肥料, 燃料採集の場として利 用されてきた二次植生ではあるが，関東以南の常緑広葉樹 林域に落葉広葉樹林時代（水期）の生物を温存するという 重要な役割を担ってきた。これが生物の生息地として里山 がはたしてきた第一の役割である。

日本の生物相には大陸と共通する種が多いことから，水 期に大陸から移動してきた種が多く含まれていると考えら れる。たとえば千葉県の北総台地の雑木林にはカタクリを はじめ畄 1 にあげた植物が生育しているが，これらはイチ リンソウが日本固有であることを除き，いずれも中国大陸， 朝鮮半島，サハリンなどにも分布している。そのことから 水期に日本が大陸と陸つづきになったとき, 朝鮮半島やサ ハリンなどを経由して入ってきたと思われる。

これらの植物が氷期の遺存種であると考えられ るのは, いずれも落葉広葉樹林に結び付いた生活 史をもち，それ故常緑広葉樹林のもとでは生活で きない生物（スプリング・エフェメラル）である こと, また常緑広葉樹林が破壊された後にそこに 移動してきたという考えではその分布が説明でき ないことなどの理由からである。

カタクリをはじめ図1にあげた植物は早春に葉 を広げ，キッネノカミソリを除きこの時期に花を 咲かせる。そして上を覆う落葉広葉樹が葉を広げ る五月になると葉を落し，翌春まで休眠する。こ れらが地上に姿を現している期間は雑木林の林床 に光が射込んでいる期間之一致する。これは落葉 広葉樹が葉を広げる前の期間にだけ林床に射込む 光で一年分の栄養を光合成してしまう仕組みなの である。

カタクリは芽生えてから花が咲くまでに $8 \sim 10$ 年かかる。またその種子はアリによって運ばれ散 布されるので, 1 回に $5 \mathrm{~m}$ 程度しか移動できない。 この移動速度から考えると, カタクリは最終水期


図一 1 北総台地 (千葉県) の雑木林に生育する春植物の季節相と 林内照度の年変化

岩瀬（1985）より書き直す（守山，1988による）

·農林水産省農業環境技術研究所 


\section{雑木林の歴史的価值}

水期には落葉広葉樹林域であった現在の暖温帯域でも気 候が温暖化すると常緑広葉樹林が北上を始めた。花粉分析 の結果によると大阪から京都までの $40 \mathrm{~km}$ 1,000〜1,500 年かけて移動している。その移動速度は年間 $30 \sim 40 \mathrm{~m}$, カタクリの移動速度（50～ $60 \mathrm{~cm} /$ 年）の数十倍になる。暖 温帯域のスプリング・エフェメラルは常緑広葉樹林のスピー ドから逃げきることができず，消える運命にあった。

現在, 管理放裹され常緑広葉樹林化が進んだ雑木林では 多くのスプリング・エフェメラルが姿を消している。それ はカタクリのような春植物だけでなく，ギフチョウやミド リシジミ類などのチョウであ同じである。このことから後 水期の温暖化に伴い, 多くのスプリング・エフェメラルが 常緑広葉樹林域から姿を消す運命だったと想像できる。

しかし花粉分析の結果からは, 常緑広葉樹林が現在ある 位置まで北上したのは意外に新しいことがわかっている。 安田（1980）, 前田（1980）によると京都付近に達したの は 5,000 4,500 年前, 縄文中期である。関東地方でも, 約 5,000 年前の北総台地は, コナラ亜属（落葉広葉樹）が アカガシ曲属（常緑広葉樹）を上回っていた（清永，1994）。 したがってこの時代の本州内陸部の暖温帯域は, 水期以降 続いてきた落葉広葉樹林と, 新に北上してきた常緑広葉樹 林が入り交じった世界であった，ということができる。

縄文中期の頃，本州にはすでに焼畑農耕が導入されてい たことが, 花粉分析や遺跡の発掘などの結果から明らかに されている。当時の人口密度や焼畑経営に必要な山林面積 から, 二次林性の落葉広葉樹林は $12 \%$ 程度に達していた と想定される（守山，1988）。

カタクリの移動速度は遅いが，20～30 年の休閑期間を もつ焼畑の場合, 耕作放棄と同時に焼畑内部へ種子が $5 \mathrm{~m}$ 運び込まれ，その種子が芽生え 10 年後に結実してさらに $5 \mathrm{~m}$ 内部にまで種子を分散させるという方式で広がってい くと，0.10〜0.16ha 以下の面積のものならば，カタクリは 休閑期間の間に焼畑の中心部まで移動できることになる。

伝統的な焼畑の 1 筆の大きさは九州の焼畑卓越地域では 約 0.3ha で, この面積は伐採に必要な労働力が制限要因と なって決まっている（佐々木，1972）。縄文時代は石斧が 使われていたと考えられるが，その伐採能力は鉄斧の 1/4（本多, 1963）～1/6（コールズ,1977）なので, 縄 文時代の焼畑の 1 回の伐採可能面積は 0.1 ha 以下であった と考えられる。縄文時代の焼畑の 1 回の伐採可能面積はこ のようにカタクリの分散可能な範囲に納まるので, カタク リは焼畑耕作のなかで生き残りえたであろう。

森林内にギャップがつくられ，ローテーションしていく 現象はヨーロッパのブナ原生林でも観察されている。そこ では 0.1〜 2 ha の大きさのギャップが倒木によって生じ, ローテーションしながらブナを極相とする落葉広葉樹林の
種多様性を保持している (Remmert,1991)。焼畑のロー テーションでも 1 回の伐採（ギャップ形成）面積はこの範 囲に納まる。そしてそのローテーションは雑木林にあ引き 継がれている。里山はこのような仕組みで落葉広葉樹林時 代の種多様性を保持してきたのだろう。

\section{二次林の配置}

里山（二次林）の役割の第二は，そこが農業に利用され てきたことを反映し, 耕地, 屋敷林などとともにモザイク を形成し，生物相を保持してきたことである。モザイク状 の配置はそれぞれの景観構成要素を不連続なすのにする。 しかもそこは人の働きかけによって維持されている系であ る。そのため農村の生物相は人の働きかけによる後退と他 からの移動による回復の動的平衡のうえに存在するという 特徴を持つ。こうした系で生物の多様性が保たれるために は, それぞれの景観構成要素が生物が移動できる間隔で配 置されていなくてはならない。

一次林は関西地方では丘陵地に集中して存在し, 平地に 散在することはほとんどない。ここでは古くからワタなど の商品作物が導入され金肥が購入できたので肥料（落葉） 採集用の二次林が不要だったからである。これに対し自給 肥料への依存度が高かった関東平野では二次林は台地のう えに散在し，耕地とのモザイクをなしてきた。

落葉を肥料にしていた時代の林の必要面積は土地面積の 25〜30\%で，茨城県つくば市周辺でも筑波研究学園都市が できる直前（1960年代）までは樹林地率はこの範囲に納 まっていた（守山，1977）。しかし学園都市建設後の樹林 地率は $16 \%$ に隇少した。

台地上の二次林は森林性の鳥が冬に平地に降りてくる際 の飛石の役目をしていたと考えられる。そこで学園都市建 設後に，森林性の鳥のおむな住処である筑波山と，そこか ら農村を通って学園都市に至るまでの 6 ヶ所の樹林の鳥相 を比較してみた。すると森林性の鳥は筑波山を離れるにし たがって種数が減ることがわかった（守山，1997，守山ほ か, 1997)。

中西（1944）によると1930 年代の武蔵野（東京都の板 橋・杉並・三鷹・深大寺を結ぶ地域）には，筑波山に近い 種数の森林性の鳥たちが冬に飛来していた。さらに江戸末 期（1824 年）の『武江産物志』を見ると, 同じ位豊かな 鳥相が江戸近郊の上野・四谷・目黒を結ぶ地域まで移動し てきていた。これらの地域はいずれもその時代には都市と 農村の接点に位置していた。このことから台地上に散在す る二次林は，伝統的農業が保たれていた時代には山の鳥が 平地へ移動する際の飛石の役目をしていたといえる。そし てその樹林地率は 25〜30\%が一つの目安になり，16\%で は少なすぎると考えられる。 


\section{溜池の配置}

里山は水源涵養林としての役割も持っている。関東平野 では台地に刻まれた浅い浸食谷を利用してっくった水田 （谷津田）が多く存在する。ここでは谷頭の部分に二次林 を仕立てるとともに溜池を設け，水涸れを防いでいる。

溜池は眝水量を維持するため数年に 1 回は泥上げされる が，そのとき水生生物は死滅する。しかし近くに別の溜池 があり，そこから生物が移動してくるならば，池に水が張 られたとき，もとの生物相はすみやかに回復するだろう。

私たちは農業環境技術研究所（茨城県つくば市）の圃場 区域（35ha）に農村環境のモデルを造成し，イトトンボ 類など，植生豊かな池沼に棲むトンボを対象に移動距離の 調査を行なったところ，多くのトンボが $1 \mathrm{~km}$ 強移動するこ とがわかった。またトンボが多数繁殖するようになった溜 池から $900 \mathrm{~m}$ ほど離れた位置に新たな溜池を造成したとこ ろ，もとの溜池で多数繁殖している種類は新たな溜池に造 成初年度から多数飛来した（守山ほか，1990，1992）。

この地域では，ほとんどの溜池が $1 \mathrm{~km}$ 以内の間隔で隣あっ ている。この間隔は多くのトンボの移動距離の範井に納まっ ているので，池の泥上げを行なってあ，あとのトンボ相は すみやかに回復するであろう。

ところでこの溜池の間隔は集落の間隔（平均 $1.35 \mathrm{~km}$; 山岡ほか, 1977）より短い。宮本（1994）は奈良盆地の溜 池は集落単位で 1 〜 ヶ所つくられていることを明らかに している。これは水が必要な時, 他の集落から水を貪うこ とが不可能なためである。つくば市周辺の溜池が集落より あ短い間隔で隣あっていることも，集落単位で溜池を持た ねばならなかったことの反映であると思われる。

\section{おわりに}

いじょう述べたように里山は生物を保持する重要な場で ある。ヨーロッパでも農業が生物相を保持してきた役割を 高く評価している。実はこうした考えが当てはまる地域は 氷期の影響を強く受けた地域なのである。

ヨーロッパでも日本同様，水期に南下してきた生物が多 く棲み, 南方系のものは少ない。それはヨーロッパでは地 中海之砂漠という二重の障壁により，南からの生物の移動 が阻まれているからである。これは後水期には海によって 南方系生物の北上が妨げられた日本とよく似ている。

ヨーロッパでも日本でも古くから人間が住み，農耕・牧 音を行なってきた結果，水期に近い景観や生物が守られて きた。伝統的な二次林や草地の管理にはこうした意味があっ たといえる。

さらに農業環境技術研究所（茨城県つくば市）の戋場区 域に農村環境のモデルを造成して調査した結果，生物にとっ て望ましい農村の姿は伝統的な農村環境にきわめて近い配 置を持つものであることがわかった（守山，1997，守山ほ
か, 1997)。里山を含めた文化景観も生物相を守る働きを してきたといえるだろう。

\section{引用文献}

1) 本多勝一（1963）：ニューギニア高地人：朝日新聞社 $241 \mathrm{pp}$.

2 ）岩瀬 徹（沼田 真・大野正男監修, 1985）：房総の 生物 p.56-59, 河出書房

3 ）清永丈太（1994）：花粉が語る照葉樹林の移動：中村 和郎・小池一之・武内和彦編，『関東』94-95，岩波 書店

4 ）コールズ J.（鈴木公雄訳）（1977）: 実験考古学：p.29, 学生社

5 ）前田保夫（1980）: 縄文の海と森 : 蒼樹書房 238pp.

6 ）宮本 誠（1994）：奈良盆地の水土史：農山漁村文化 協会 309pp.

7 ）守山 弘（1988）：自然を守るとはどういうことか： 農山漁村文化協会 $260 p p$.

8 ) 守山 弘・山岡景行・重松 孟（1977）：農業地帯に おける二次林, 屋敷林の歴史的位置づけ：東洋大学紀 要教養課程篇（自然科学） No.20,35-49

9 ）守山 弘・飯島 博・原田直国（1990）: トンボの移 動距離をとおしてみた湿地生態系のありかた：人間と 環境 15(3),2-15

10）守山 弘・飯島 博・白木彩子・長田光世（1992）: 谷津田環境の配置がもつトンボの種供給機能 : 環境情 報科学 21(2),84-88

11）守山弘（1997）：むらの自然をいかす：岩波書店 $128 p$.

12）守山 弘・原田直國・井手 任（1997）：農村環境の 生物保持機能に着目したビオトープ結合システム：農 業環境技術研究所年報 平成 7 年度 46-55

13）中西悟堂 (1944)：狭義武蔵野の鳥：野鳥 11(2),108142

14) Remmert, H. (1991) : The mosaic-cycle concept of ecosystems : In The mosaic cycle concept of ecosystems 1-21 Springer-Verlag

15）佐々木高明（1972）: 日本の焼畑：古今書院 $457 \mathrm{pp}$.

16）山岡景行・守山 弘・重松 孟（1977）: 歴史的農業 地帯における屋敷林, 二次林の生態学的役割 : 東洋大 学紀要教養課程篇（自然科学） No.20,17-33

17）安田喜憲（1980）：環境考古学事始：日本放送出版協 会 270pp. 